\title{
Effect of moisture stress, plant population density and pathogen inoculation on charcoal stalk rot of sorghum*
}

\author{
By S. PANDE, L. K. MUGHOGHO and R. I. KARUNAKAR \\ International Crops Research Institute for the Semi-Arid Tropics (ICRISAT), \\ Patancheru P.O., Andhra Pradesh 502 324, India
}

(Accepted 7 November 1989)

\begin{abstract}
Summary
The effects of moisture deficit stress, plant population density and pathogen inoculation technique on charcoal stalk rot in the sorghum hybrid CSH 6 were studied in the 1980-81 and 1981-82 post-rainy seasons at three locations in India. Incidence and severity of charcoal rot caused by Macrophomina phaseolina were compared in three plant population densities, subjected to different moisture stress regimes created by withholding irrigation at various plant growth stages. Natural infections were compared to artificial inoculation with $M$. phaseolina. Combinations of moisture stress, plant population and inoculation treatments were compared to identify the combination most likely to develop maximum disease. Lodging, the first external symptom of charcoal rot, was significantly correlated with other disease symptoms used to measure charcoal rot, such as soft stalk, number of nodes crossed by $M$. phaseolina infection, root damage and plant senescence. In both seasons the highest incidence of lodging occurred when moisture stress was induced at the 'flag leaf visible in the whorl' growth stage. The greatest incidence of the disease was recorded in the highest plant population (266 700 plant ha.t) at all three locations. No significant differences were found between artificially and naturally inoculated treatments. The maximum number of lodged plants was found at a density of 266700 plants ha $^{-1}$ when moisture stress was induced at the 'flag leaf visible in the whorl' growth stage.
\end{abstract}

Key words: Charcoal rot, Macrophomina phaseolina, moisture stress, plant density, root infection, lodging, plant senescence

\section{Introduction}

Charcoal stalk rot of sorghum (Sorghum bicolor (L.) Moench) caused by Macrophomina phaseolina (Tassi) Goid. occurs most often when vigorously growing sorghum fills grain under moisture stress (Edmunds, 1964; Odvody \& Dunkle, 1979). Symptoms of the disease include root discolouration, root rots, soft stalks and lodging of plants, premature drying of stalks and poorly developed panicles with small, inferior quality grains (Uppal, Kolhatkar \& Patel, 1936; Tarr, 1962). Vascular bundles of infected roots and stalks are profusely covered with tiny charcoal coloured sclerotia of the fungus that give the name charcoal rot to the disease (Livingston, 1942). Several crop management practices have been reported to influence charcoal rot development. In mixed cropping sorghum has been reported to suffer less charcoal rot damage than in a sole crop (Khune, Shiwankar \& Wangikar, 1980). Wadsworth \& Sieglinger (1950) observed more charcoal rot in unspecified close spacing, and Patil, Deshamane \& Pandhare (1982) noted cultivar differences in the incidence of charcoal rot at different plant -ICRISAT Journal Article No. 717

(C) 1990 Association of Applied Biologists 
populations. Studies on the effect of plant population on the incidence of sorghum charcoal stalk rot are important because of the desirability of increasing plant populations to achieve greater yields.

Several workers have investigated factors affecting charcoal rot development under greenhouse conditions (Livingston, 1945; Hsi, 1961; Edmunds, 1964). Data from field experiments that describe the combined effect of moisture stress, plant population and pathogen inoculation on sorghum charcoal rot are not available. Experiments were therefore conducted to investigate the effect of different plant population densities on disease development, identify the plant growth stage when moisture stress is most likely to induce disease development, compare the effectiveness of inoculation methods and identify the combination of these three factors that is most likely to favour disease development. Such information would be useful in the selection of charcoal rot resistant sorghum cultivars in a screening programme.

\section{Materials and Methods}

\section{Location}

The experiment was conducted in an Alfisol at the experimental farm of the International Crops Research Institute for the Semi-Arid Tropics (ICRISAT), Patancheru (latitude $17^{\circ} 30^{\prime} \mathrm{N}$, longitude $78^{\circ} 18^{\prime} \mathrm{E}$ ) and in a Vertisol at the University of Agricultural Sciences, Dharwad (latitude $15^{\circ} 28^{\prime} \mathrm{N}$, longitude $75^{\circ} 2^{\prime} \mathrm{E}$ ) in 1980-1981 and 1981-1982 post-rainy seasons. In 1981-1982 the experiment was also conducted in a Vertisol at the Andhra Pradesh Agricultural University Regional Agricultural Research Station, Nandyal (latitude $15^{\circ} 29^{\prime} \mathrm{N}$, longitude $\left.78^{\circ} 32^{\prime} \mathrm{E}\right)$.

\section{Season}

The post-rainy season, from the end of September to March, is usually dry with little precipitation. In 1980-1981 the experiment was sown on 11 November 1980 at Patancheru and on 1 December 1980 at Dharwad. Throe rainy days (24 December $1980=2 \mathrm{~mm}, 11$ January $1981=7.6 \mathrm{~mm}$ and 12 March $1981=19.8 \mathrm{~mm}$ ) were recorded at Patancheru and two rainy days (2 December $1980=0.5 \mathrm{~mm}$ and $18 \mathrm{January} 1981=2.5 \mathrm{~mm}$ ) at Dharwad. In 1981-1982 the experiment was sown on 9,26 and 29 November 1981 at Patancheru, Dharwad and Nandyal, respectively, and no precipitation occurred during the entire period of the experiment. Daily maximum and minimum air temperature records were obtained from the meteorological stations at their respective locations.

\section{Experimental design}

The design was a split-split-plot with six replications. Moisture stress treatments were assigned to the main plot, plant population densities to the sub-plots and inoculations to the sub-subplots. Each sub-sub-plot consisted of eight $4 \mathrm{~m}$ rows spaced $0.75 \mathrm{~m}$ apart. The central six rows were assessed for the disease.

\section{Plant populations and fertilisation}

Certified seed of the charcoal rot susceptible sorghum hybrid CSH 6, procured from the National Seeds Corporation of India, was sown at a higher seed rate $\left(35 \mathrm{~kg} \mathrm{ha}^{-1}\right)$ than normal (10 kg ha-1). Initially a thick crop stand was obtained and 10 days after emergence thinned to establish three plant populations [66 $675\left(D_{1}\right), 133350\left(D_{2}\right)$ and $266700\left(D_{3}\right)$ plants ha-1], by adjusting plant spacing within the rows. 
A basal dose of $40 \mathrm{~kg} \mathrm{~N}$ (urea), $40 \mathrm{~kg} \mathrm{P}$ (single superphosphate) and $40 \mathrm{~kg} \mathrm{~K}$ (muriate of potash) $\mathrm{ha}^{-1}$ was mixed by harrowing into the ploughed and harrowed soil at planting. Thirty days after emergence the crop was top dressed with an additional $40 \mathrm{~kg} \mathrm{~N} \mathrm{ha}^{-1}$ of urea.

\section{Moisture stress}

Irrigation was given at planting and once every 11 days in Alfisols and once every 21 days in Vertisols from emergence until the crop reached the growth stage for initiation of the moisture stress treatments: (1) irrigation stopped at the 'flag leaf visible in the whorl' stage (stress-1), (2) irrigation stopped at 'boot' stage (stress-2), (3) irrigation stopped at $50 \%$ flowering (stress-3) and (4) irrigation stopped at physiological maturity (stress-4). The stress- 4 treatment was not included in the $1980-1981$ season.

\section{Inoculations}

Two inoculation treatments $\left(I_{1}=\right.$ sterile toothpick and $\mathrm{I}_{2}=M$. phaseolina-infested toothpick) were compared with a natural inoculation treatment ( $I_{0}=$ natural soilborne inoculum) in the 1980-1981 season at Dharwad and in the 1981-1982 season at Patancheru, Dharwad and Nandyal. Only two inoculation treatments $\left(I_{1}\right.$ and $\left.I_{2}\right)$ were included at Patancheru in the 1980-1981 experiment. Toothpicks were infested and stalks were inoculated at the second internode as described by Rao, Reddy, Williams \& House (1980).

\section{Plant protection}

Plant damage by the shoot fly (Atherigona soccata Rondani) and stem borer (Chilo partellus Swinhoe) was controlled by application of carbofuran (2,3-dihydro-2,2-dimethyl-7-benzofuranyl methyl carbamate) granules at the rate of $15 \mathrm{~g} / 4 \mathrm{~m}$ row with the seed at planting, followed by sprays of endosulfan $0.35 \%$ a.i. at intervals of 10 days from 30 days after plant emergence to flowering.

\section{Observations}

Seven days after physiological maturity the various parameters relating to the incidence of charcoal rot were assessed on plants from the central six rows of each plot. The amount of lodging, the first external symptom of the disease, was determined by counting the number of lodged plants in each plot. The stalk of each plant was then squeezed between two fingers and thumb at the second internode above the soil level to assess the destruction of the internal structure and the numbers observed were expressed as the percentage with soft stalk. Plants were then uprooted to examine the extent of root damage which was expressed as percent root infection and scored visually on a $1-5$ scale $(1=$ no discolouration and infection, 2 $=$ less than $10 \%$ roots showing discolouration and infection, $3=11-25 \%$ roots showing discolouration and infection, $4=26-50 \%$ roots showing discolouration and infection, and $5=$ more than $50 \%$ roots showing discolouration and infection). Root infection was determined by observing the percentage of plants with sclerotia in the roots. Stalks were split open to measure the extent of fungal colonisation (based on the presence of sclerotia) of the stem, as indicated by the number of nodes crossed by the fungus from the first node above soil level.

The extent of damage to plants was assessed (plant senescence) on a 1-5 scale, where $1=$ foliage and stalk completely green, 2 = less than $10 \%$ foliage and stalk brown and dry, 3 $=25 \%$ foliage and stalk brown and dry, $4=50 \%$ foliage and stalk brown and dry, and 5 = complete death of foliage and stalk (Rosenow, 1980).

In 1981-1982, lodged plants were also counted at intervals from the initiation of lodging to 7 days after physiological maturity (black layer formation in the grain). 
Data for each location and season were analysed separately and correlations were considered between different disease parameters to identify the most suitable parameters for estimating charcoal rot severity.

\section{Results}

\section{Weather}

Figs 1 and 2 present meteorological data for each season and location for each successive 7-day period. The crop matured between 102 to 122 days after sowing dependent on location and season. In 1980-1981 the total rainfall during the growing season was, respectively, 29 $\mathrm{mm}$ and $3 \mathrm{~mm}$ at Patancheru and Dharwad. Out of $29 \mathrm{~mm}$ rain, $20 \mathrm{~mm}$ were received during harvesting at Patancheru, and thus did not interfere with the irrigation schedule selected to impose moisture stress at various plant growth stages in the experiment. There was no rainfall during the 1981-1982 experimental period at any of the locations (Fig. 2). In both seasons maximum and minimum air temperatures ranged between $28-35^{\circ} \mathrm{C}$ and $10-20^{\circ} \mathrm{C}$, respectively, across all locations (Figs 1 and 2).
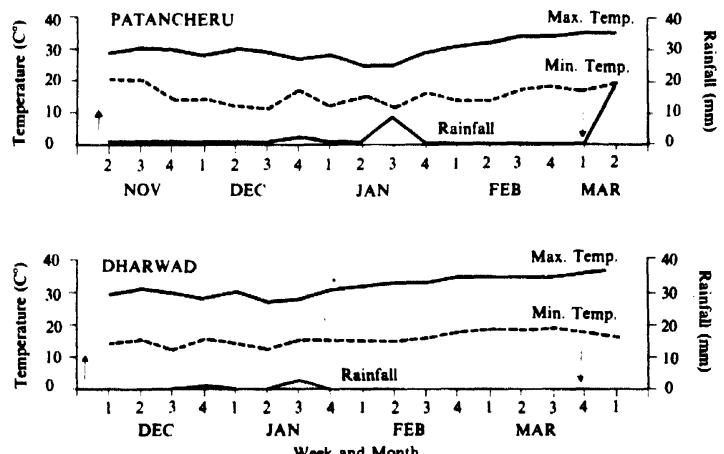

Fig. 1. Weekly average temperuture and rainfall at Patancheru, (November 1980-March 1981) and Dharwad (December 1980 - March 1981). $(\uparrow)$ and $(\downarrow)$ are planting date and physiological maturity, respectively.

\section{Moisture stress}

Tables 1 and 2 show the effects of moisture stress treatments on percent lodging (charcoal rot incidence) in the 1980-1981 and 1981-1982 experiments. At Patancheru and Nandyal significantly higher lodging occurred in stress-1 treatments and fewer plants lodged with reduced duration of moisture stress. At Dharwad, the moisture stress treatments stress-1, stress-2 and stress-3 did not differ significantly in 1980-1981, nor did stress-1 and stress-2 in 1981-1982. However, more lodging occurred at Dharwad in 1981-1982 than in 1980-1981. 

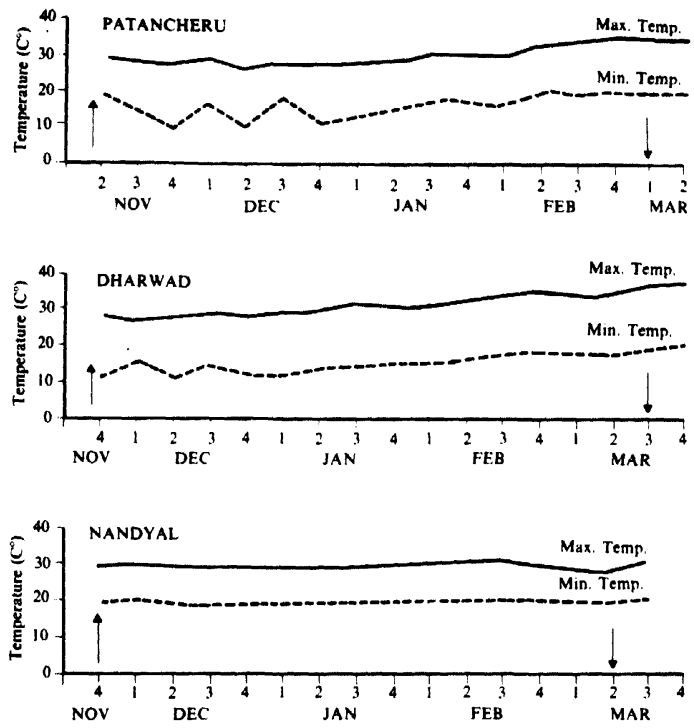

Week and Month

Fig. 2. Weekly average temperature at Patancheru. Dharwad and Nandyal. (November 1981 . March 1982). $(t)$ and $(\downarrow)$ are planting date and physiological maturity, respectively.

In 1981-1982 lodging began at different times and at different growth stages, in different locations (see Fig. 3). At Patancheru lodging started at 92 days (soft dough growth stage), at Dharwad at 86 days (milk growth stage) and at Nandyal at 70 days (early milk growth stage) after emergence. The test sorghum hybrid, CSH 6, took 102, 100 and 95 days to reach the hard dough stage at Patancheru, Dharwad and Nandyal, respectively. The rate of increase in the number of lodged plants varied among locations. The maximum number of lodged plants occurred between the hard dough stage and physiological maturity. Increase in percent lodging was relatively higher in stress-1 treatments at all locations (Fig. 3).

\section{Plant population}

In both the 1980-1981 and 1981-1982 seasons lodging (charcoal rot) increased with increasing plant populations. At all three locations the maximum number of lodged plants occurred at the highest plant population (Tables 1 and 2). Periodical counts of lodged plants in 1981-1982 revealed that the increase in charcoal rot incidence was proportionately higher in plant population $D_{3}$ than $D_{2}$ and $D_{1}$ (Fig. 3). Charcoal rot development (\% lodging) at Dharwad 

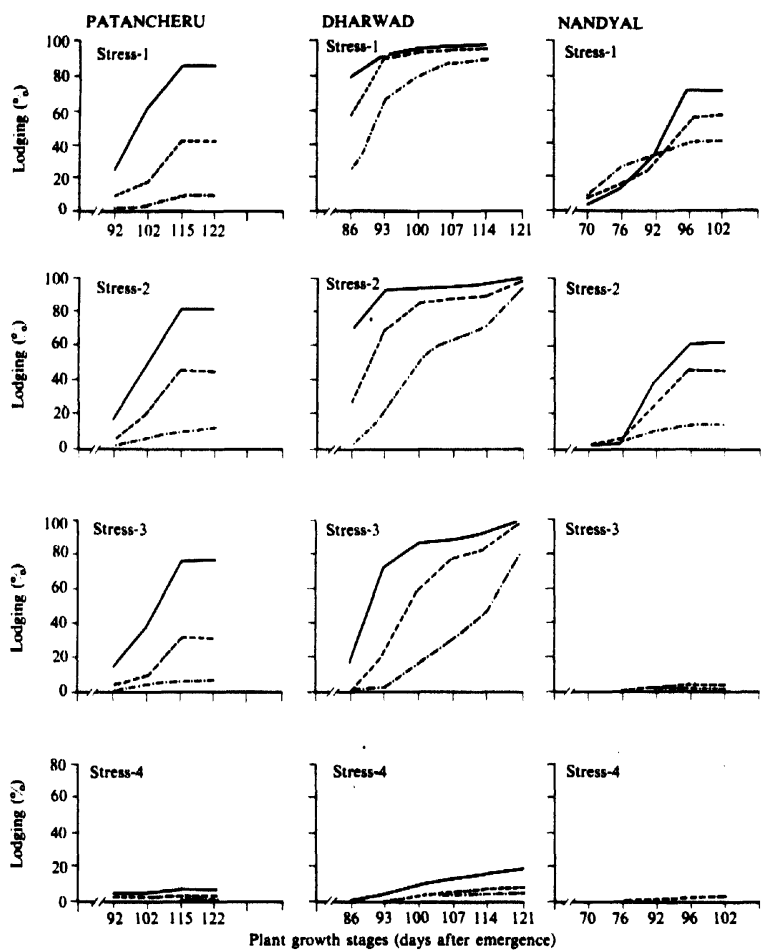

Fig. 3. Percent lodging with time in four moisture streas regimes and three plant population densities at three locations (Patancheru, Dharwad and Nandya) during the 1981-82 post-rainy season. (._._-_.), $(--)$, and $(-)$ are density-1, density-2 and density-3, respectively.

was almost the same in all three plant populations and moisture stress treatments (stress-1, stress-2 and stress-3) in 1981-1982 (Table 2). Charcoul rot incidence was at a maximum between hard dough growth stage and physiological maturity in the three plant populations (Fig. 3). 
Table 1. Percent lodging in the sorghum hybrid CSH 6 at three moisture stress levels and three plant population densities at Patancheru and Dharwad in the 1980-1981 post-rainy

\begin{tabular}{|c|c|c|c|c|}
\hline $\begin{array}{c}\text { Moisture } \\
\text { stress } \\
\text { level* }\end{array}$ & $\begin{array}{c}\text { Plant } \\
\text { population } \\
\text { density*" }\end{array}$ & \multicolumn{3}{|c|}{ Percent lodging } \\
\hline \multicolumn{5}{|l|}{ Stress - 1} \\
\hline & $D_{1}$ & 0.8 & 28.9 & 14.9 \\
\hline & D: & 32.8 & 54.0 & 43.4 \\
\hline & $D_{3}$ & 58.8 & 69.9 & 64.4 \\
\hline & Mean & 30.8 & 50.9 & 40.9 \\
\hline \multicolumn{5}{|l|}{ Stress - 2} \\
\hline & $D_{1}$ & 0.5 & 13.8 & 7.1 \\
\hline & D: & 19.4 & 45,0 & 32.2 \\
\hline & $D_{1}$ & 41.5 & 70.7 & 56.1 \\
\hline & Mean & 20.5 & 43.2 & 31.8 \\
\hline \multicolumn{5}{|l|}{ Stress - 3} \\
\hline & $D_{1}$ & 0.1 & 6.8 & 3.5 \\
\hline & D, & 9.7 & 41.4 & 25.6 \\
\hline & $\mathrm{D}_{3}$ & 16.4 & 77.5 & 47.0 \\
\hline & Mean & 8.7 & 41.9 & 25.3 \\
\hline Mean (stress) & & 20.0 & 45.3 & 32.7 \\
\hline Mean & $D_{1}$ & 0.5 & 16.5 & 8.5 \\
\hline Mean & $D_{2}$ & 20.6 & 46.8 & 33.7 \\
\hline Mean & $\mathrm{D}_{3}$ & 38.9 & 72.7 & 55.8 \\
\hline \multicolumn{2}{|c|}{ S.E. for stress $(D . F=2)$} & \pm 2.93 & \pm 3.67 & \\
\hline \multirow{2}{*}{\multicolumn{2}{|c|}{$\begin{array}{l}\text { S.E. for density }(D . F .=2) \\
\text { S.E. for stress } \times \text { density }(D . F .=4)\end{array}$}} & \pm 3.36 & \pm 2.73 & \\
\hline & & \pm 4.76 & \pm 4.73 & \\
\hline \multicolumn{5}{|c|}{$\begin{array}{l}\text { - Stress }-1=\text { irrigation stopped at 'flag leaf visible in the whorl' growth stage. } \\
\text { Stress - } 2=\text { irrigation stopped at 'boot' stage. } \\
\text { Stress - } 3=\text { irrigation stopped at } 50 \% \text { flowering. }\end{array}$} \\
\hline
\end{tabular}

\section{Inoculations}

In 1980-1981 no significant differences in percent lodging were obtained between inoculation treatments at Patancheru and Dharwad (Table 3). In the second season (1981-1982) $M$. phaseolina infested toothpick inoculation $\left(\mathrm{I}_{2}\right)$ showed, 4-5, 2-4 and $9 \%$ more lodged plants (calculated as the differences in percent lodging between $I_{2}$ and $I_{1}$, and $I_{2}$ and $I_{0}$ inoculation treatments for each location and expressed as a range) than the other two inoculation treatments $\left(I_{1}\right.$ and $\left.I_{0}\right)$ at Patancheru, Dharwad and Nandyal, respectively. In the same season the difference between the natural infection $\left(l_{0}\right)$ and sterilised toothpick inoculation $\left(l_{1}\right)$ was not significant (Table 3). In general, considerable differences were not obtained between inoculation treatments tested in the two seasons.

\section{Moisture stress, plant populations and charcoal rot}

A combination of the highest plant population density (266 700 plants ha-1) and moisture stress level (stress-1) produced the highest percentage of lodged plants when averaged over two test locations in the 1980-1981 and three in the 1981-1982 seasons (Tables 1 and 2). 
Table 2. Percent lodging in the sorghum hybrid CSH 6 at three moisture stress levels and three plant population densities at Patancheru, Dharwad and Nandyal in the 1981-1982 post-rainy season

\begin{tabular}{|c|c|c|c|c|c|}
\hline $\begin{array}{l}\text { Moisture } \\
\text { stress: } \\
\text { level* }\end{array}$ & $\begin{array}{c}\text { Plant } \\
\text { population } \\
\text { density"* }\end{array}$ & Patuncheru & $\begin{array}{l}\text { Percen } \\
\text { Dharwad }\end{array}$ & Nandyal & Meat \\
\hline \multicolumn{6}{|l|}{ Strens - 1} \\
\hline & $\mathrm{D}_{1}$ & 23.7 & 100.0 & 39.3 & 54.3 \\
\hline & $\mathrm{D}_{2}$ & 61.7 & 100.0 & 50.9 & 70.9 \\
\hline & $D_{3}$ & 81.3 & 100.0 & 70.1 & 83.8 \\
\hline & Mean & 55.6 & 100.0 & 53.4 & 69.7 \\
\hline \multicolumn{6}{|l|}{ Stress -2} \\
\hline & $D_{1}$ & 16.9 & 95.4 & 15.3 & 42.5 \\
\hline & $D_{2}$ & 49.5 & 98.9 & 46.4 & 64.9 \\
\hline & $D_{3}$ & 81.8 & 100.0 & 62.0 & 81.3 \\
\hline & Mean & 49.4 & 98.1 & 41.2 & 62.9 \\
\hline \multicolumn{6}{|l|}{ Stress -3} \\
\hline & $D_{1}$ & 15.0 & 78.1 & 2.2 & 31.8 \\
\hline & $D_{2}$ & 33.9 & 96.9 & 2.5 & 44.4 \\
\hline & $D_{3}$ & 76.2 & 98.8 & 1.3 & 58.8 \\
\hline & Mean & 41.7 & 91.3 & 2.0 & 45.0 \\
\hline \multicolumn{6}{|l|}{ Stress 4} \\
\hline & $D_{1}$ & 5.7 & 3.9 & 1.5 & 3.7 \\
\hline & $\mathrm{D}_{2}$ & 5.1 & 6.8 & 0.8 & 4.2 \\
\hline & $D_{3}$ & 5.4 & 19.1 & 0.7 & 8.4 \\
\hline & Mean & 5.4 & 9.9 & 1.0 & 5.4 \\
\hline \multicolumn{2}{|l|}{ Mean (stress) } & 38.0 & 74.8 & 24.4 & 45.7 \\
\hline Mean & $D_{1}$ & 15.3 & 693 & 14.6 & 33.1 \\
\hline Mean & $\mathrm{D}_{2}$ & 37.5 & 75.6 & 25.1 & 46.1 \\
\hline Mean & $\mathrm{D}_{3}$ & 61.2 & 79.5 & 33.5 & 58.1 \\
\hline \multicolumn{2}{|c|}{ S.E. for stress (D.F. $=3$ ) } & \pm 3.88 & \pm 1.52 & \pm 4.70 & \\
\hline \multirow{2}{*}{\multicolumn{2}{|c|}{$\begin{array}{l}\text { S.E. for density }(D . F .=2) \\
\text { S.E. For stress } \times \text { density }(D . F .=6)\end{array}$}} & \pm 2.41 & \pm 1.22 & \pm 2.42 & \\
\hline & & $\pm 4,82$ & \pm 2.44 & \pm 4.84 & \\
\hline \multicolumn{5}{|c|}{ 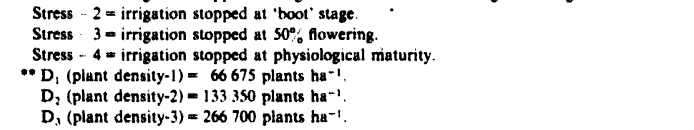 } & \\
\hline
\end{tabular}

In both years various other combinations of moisture stress and plant population density produced effects almost as severe as the highest percentage of infection. For example, in $1980-1981$ the most serious lodging $(70-77 \%)$ was recorded at the highest plant population density $\left(D_{3}\right)$ in all the three moisture stress levels at Dharwad (Table 1). In 1981-1982 the three plant population densities $\left(D_{1}, D_{2}\right.$ and $\left.D_{3}\right)$ in two moisture stress levels (stress-1 and stress-2) and two plant population densities $\left(D_{2}\right.$ and $\left.D_{3}\right)$ in stress-3 treatments did not differ significantly and produced above $95 \%$ lodged plants at Dharwad (Table 2). Similarly in the same season no significant differences in lodging percentage were obtained in highest plant population densities in stress-1, stress-2 or stress-3 treatments at Patancheru and in stress-1 and stress-2 treatments at Nandyal (Table 2). 
Table 3. Percent lodging in the sorghum hybrid CSH 6 subjected to three inoculation treatments at Patancheru, Dharwad and Nandyal during the 1980-1981 and 1981-1982 post-ruiny seasons

\begin{tabular}{|c|c|c|c|c|c|c|}
\hline \multirow{3}{*}{$\begin{array}{l}\text { Inoculation } \\
\text { treatments" }\end{array}$} & \multicolumn{6}{|c|}{ Percent lodging } \\
\hline & & $1980-1981$ & & & 1981.1982 & \\
\hline & Patancheru & Dharwad & Nandyal & Patancheru & Dharwad & Nandy \\
\hline $\mathbf{I}_{0}$ & 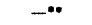 & 44.8 & - & 37.7 & 73.0 & 21.5 \\
\hline$I_{1}$ & 15.2 & 43.5 & $\cdots$ & 36.3 & 74.7 & 21.5 \\
\hline $\mathrm{I}_{2}$ & 19.8 & 47.6 & - & 41.3 & 76.6 & 30.2 \\
\hline Mean & 17.5 & 45.3 & - & 38.4 & 74.8 & 24.4 \\
\hline S.E. (D.F. $=2) \bullet \bullet$ & \pm 1.64 & \pm 1.60 & - & \pm 1.29 & \pm 0.59 & \pm 1.23 \\
\hline $\begin{array}{r}I_{0}=\text { natural } \\
I_{1}=\text { sterilised } \\
I_{2}=M \text {. phase } \\
\cdots \text { Not include } \\
\cdots \text { Patancher }\end{array}$ & $\begin{array}{l}\text { on. } \\
\text { pick inserte } \\
\text { infested toot } \\
980-1981 \text { sea } \\
=1 \text { in } 1980\end{array}$ & $\begin{array}{l}0 \text { internode } \\
\text { inserted }\end{array}$ & $\begin{array}{l}\text { econd int } \\
\text { ectem. }\end{array}$ & de of the ste & & \\
\hline
\end{tabular}

in Table 4. Lodging was positively correlated with soft stalk, mean number of nodes crossed (spread of $M$. phaseolina infection up the stem), root infection and senescence rating. The same relationship between disease parameters was observed in the 1980-1981 season.

\section{Discussion}

With regard to moisture stress there was a definite increase in lodging when the moisture stress period was increased. Moisture stress, though imposed as early as the growth stage when the 'flag leaf was visible in the whorl', did not cause a high level of stalk lodging until the crop reached the hard dough growth stage, at all locations (Fig. 3). The test hybrid, CSH 6, took 102, 100 and 95 days after emergence to reach the hard dough stage at Patancheru, Dharwad and Nandyal, respectively. These results support earlier reports of Hsi (1961) and Edmunds (1964).

The results obtained from the three locations suggest the importance of soil type and environmental conditions, associated with the gradual depletion of soil moisture during grain filling, on the incidence of lodging. During 1980-1981 and 1981-1982 there were no significant differences in charcoal rot ( $\%$ lodging) in the three moisture stress treatments at Dharwad. The soils at Dharwad are shallow Vertisols with more gravel than at Nandyal. It was presumed that the depletion of moisture in such soil was greater and faster than in the deep Vertisols of Nandyal, which have a higher clay content and water holding capacity. Edmunds, Voigt \& Carasso (1964) and Hsi (1956) reported high charcoal rot development in sorghums grown in lighter, sandy soils with low water holding capacity.

The results also show a significant increase in the incidence of charcoal rot across locations in each season, with increasing density of plant population. These results support the previous reports of Wadsworth \& Sieglinger (1950) and Patil et al. (1982). It appears that high plant populations increased interplant competition for available soil moisture at grain filling, and predisposed plants to charcoal rot.

In 1981-1982 there were no significant differences among three plant population densities in three moisture stress levels at Dharwad (Table 2). It was presumed that in the shallow vertisols of Dharwad the depletion of soil moisture in the later treatments (stress-2 and stress-3) was faster than in the stress-1 treatment, and the critical moisture stress needed for predisposition of sorghum to charcoal rot infection and development was reached at the same 


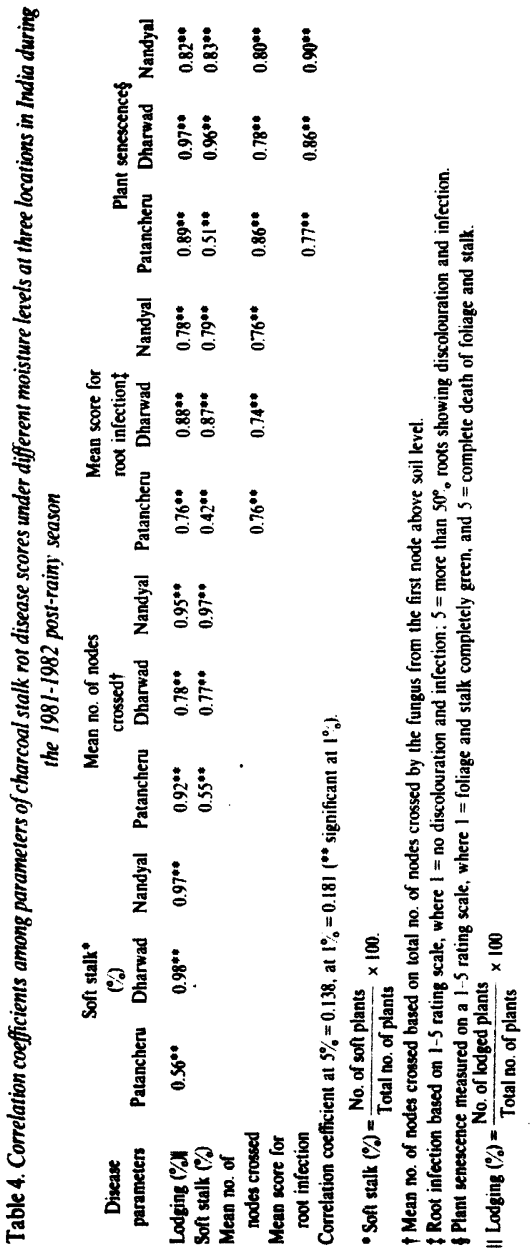


time in these three moisture stress treatments. Consequently the effect of plant population densities on the development of charcoal rot (\% lodging) was only apparent in the carly stage of the period of moisture stress. Later on, with the further decrease in soil moisture, no significant differences in lodging were recorded in the three plant population densities in all three stress treatments (Fig. 3). This result suggests that in environments and soil types similar to those at Dharwad, moisture stress created even at $50 \%$ flowering (stress-3) and a low plant population density of 66675 plants $\mathrm{ha}^{-1}$ are sufficient to bring about substantial charcoal rot disease and lodging.

The combined effect of moisture stress and higher plant population densities resulted in more lodging and charcoal rot. In the longest duration moisture stressed treatment, plant senescence ratings were highest at physiological maturity, whereas in the non-moisture-stressed treatment leaves remained green, stalks were juicy and free from charcoal rot. These results point to the usefulness of delayed senescence as a selection factor for charcoal rot resistance (Rosenow, 1984).

Several workers have studied charcoal rot development under heat and moisture stress conditions during grain filling in greenhouses using different artificial inoculation techniques with $M$. phaseolina (Livingston, 1945; Hsi, 1961; Edmunds, 1964). Rao et al. (1980) inoculated moisture-stressed plants with $M$. phaseolina infested toothpicks under field conditions. The results presented here did not indicate any advantage in the use of artificial inoculations of moisture-stressed plants with infested toothpicks, a technique which circumvents the natural infection process, but revealed the effectiveness of natural infection through roots, where plants had been sufficiently moisture stressed.

The observations presented here on root damage showed that lodged plants had diseased and discoloured roots (Table 4). There were no necrotic and discoloured roots in the treatment where plants were irrigated up to physiological maturity (stress-4). However, little is known about root infection and more detailed investigations are required.

Lodging reported by several workers (Uppal et al., 1936; Hsi, 1956; Edmunds et al., 1964) as the first observable indication of charcoal rot has been widely used as a criterion for charcoal rot evaluation (Rosenow, 1984; Duncan, 1984) and was found to be strongly correlated with other disease traits (Table 4). This result confirms the reliability of using lodging scores and delayed senescence as selection criteria for resistance.

\section{Acknowledgements}

The authors thank Dr G. R. Padaki and Dr Y. Gurunadha Rao of the Andhra Pradesh Agricultural University Regional Agricultural Research Station, Nandyal for providing facilities to conduct experiments at Nandyal.

\section{References}

Duncan, R. R. (1984). The association of plant senescence with root and stalk diseases in sorghum. In Sorghum Root and Stalk Rots: A Critical Review, pp. 99-110. Eds L. K. Mughogho and G. Rosenberg. Patancheru, India: ICRISAT.

Edmuads, L. K. (1964). Combined relation of plant maturity, temperature, and soil moisture to charcoal stalk rot development in grain sorghum. Phytopathology 54, 514-517.

Edmunds, L. I., Voizt, R. L. \& Canswo, F. M. (1964). Use of Arizona climate to induce charcoal rot in grain sorghum. Plant Disease Reporter 48, 300-302. 
Ha, C. H. (1956). Stalk rots of sorghum in eastern New Mexico. Plant Disease Reporter 40, 369-371.

Ha, C. H. (1961). An effective technique for screening sorghum for resistance to charcoal rot. Phytopathology 51, 340-341.

Khune, N. N., Shtwankar, S. K. Wanelkar, P. D. (1980). Effect of mixed cropping on the incidence of charcoal rot of sorghum. Food Farming and Agriculture 12, 292-293.

Uivingaton, J.E. (1942). Charcoal rot - threat to Nebraska corn and sorghums. Report of the Nebraska State Board of Agriculture for 1942, pp. 206-207.

Livingston, J. E. (1945). Charcoal rot of corn and sorghum. Nebraska Agriculture Experiment Station Bulletin No. 136, Lincoln, U.S.A: University of Nebraska, 32 pp.

Odvody, G. N. \& Dunkle, L. D. (1979). Charcoal stalk rot of sorghum: Effect of environment on hostparasite relations. Phytopathology $69,250-254$.

Patll, R. C., Deshamane, N. B. \& Pandhare, T. M. (1982). Effect of plant density and row spacing on charcoal rot incidence in four cultivars of sorghum. Sorghum Newsletter $25,110$.

Reo, K. N., Reddy, V.S., Wullams, R. J. \& House, L. R. (1980). The ICRISAT charcoal rot resistance program. In Sorghum Diseases, $A$ World Review, pp. 315-321. Eds R. J. Williams, R. A. Frederiksen, L. K. Mughogho and G. D. Bengtson. Patancheru, India: ICRISAT.

Rosenow, D. T. (1980). Stalk rot resistance breeding in Texas. In Sorghum Diseases, $A$ World Review, pp. 306-314. Eds R. J. Williams, R. A. Frederiksen, L. K. Mughogho and G. D. Bengtson. Patancheru, India: ICRISAT.

Rosenow, D. T. (1984). Breeding for resistance to root and stalk rots in Texas. In Sorghum Root and Stalk Rots: A Critical Review, pp. 209-218. Eds L. K. Mughogho and G. Rosenberg. Patancheru, India: ICRISAT.

Tarr, S. A. J. (1962). Diseases of sorghum, sudan grass and broom corn. Commonwealth Mycological Institute, Kew, Surrey, England. 380 pp.

Uppal, B. N., Kolhatkar, K. G. \& Patel, M. K. (1936). Blight and hollow-stem of sorghum. Indian Journal of Agricultural Science 6, 1323-1334.

Wadsworth, D. F. Sieglinger, J. B. (1950). Charcoal rot of sorghum. Oklahoma Agricultural Experiment Station Bulletin No. B-355, 7 pp.

(Received 17 August 1988) 